\title{
Baltic larval cod Gadus morhua are infested with a protistan endoparasite in the yolk sac
}

\author{
Benedikte Hedegaard Pedersen ${ }^{1}$, Kurt Buchmann ${ }^{2}$, Marianne Køie ${ }^{1}$ \\ ${ }^{1}$ Marine Biological Laboratory, University of Copenhagen, DK-3000 Helsingor, Denmark \\ ${ }^{2}$ Section of Fish Diseases, The Royal Veterinary and Agricultural University, Bülowsvej 13, DK-1870 Frederiksberg C, \\ Denmark
}

\begin{abstract}
A protistan endoparasite was discovered in the yolk of embryos and larvae of cod Gadus morhua L. from the Baltic. The prevalence of infestation ranged from 0 to $30 \%$. Two stages of the parasite were identified under transmission electron microscopy. One stage was apparently mononucleated; the other stage was multinucleated and seemed to be breaking-up into numerous, mononucleated organisms. The endoparasite is compared with the single example in the literature of infestations in the yolk of marine fish larvae - caused by the dinoflagellate Ichthyodinium chabelardi - and the consequences for larval health are briefly discussed.
\end{abstract}

\section{INTRODUCTION}

It is well documented that marine fish larvae can be infested by a variety of endo- and ectoparasites, some of which are transmitted by ingested copepods. Rosenthal (1967) ascribed $10 \%$ of the mortality in larval herring Clupea harengus to such infestations. In the literature, however, there is only one example of endoparasitic infestations in eggs and larvae on an endogenous food supply (Hollande \& Cachon 1952, 1953). Hollande \& Cachon (1953) discovered an endoparasitic dinoflagellate in the yolk of sardine Sardinus pilchardus eggs. The infested eggs developed normally, but the resulting yolk-sac larvae died due to the parasite rupturing the yolk sac. The prevalence of infestation in the Bay of Algiers varied between 30 and $80 \%$, and the parasite could constitute a limitation on reproduction in the sardine (Hollande \& Cachon 1953). The present paper deals with the finding of a protistan endoparasite in the yolk of eggs and larvae of cod Gadus morhua from the Bornholm Basin in the Baltic Sea.

\section{MATERIALS AND METHODS}

Eggs from several mature cod, caught in the Baltic near the island of Bornholm: were artificially fertilised with sperm from many males and incubated in running, recirculated seawater taken from a depth of approximately $80 \mathrm{~m}$ in the Bornholm Basin. Salinity was 16 ppt. Two batches of embryonated eggs, Batches 1 and 3 (see Table 1), were transferred to Helsingor, where salinity was gradually raised to $30 \mathrm{ppt}$, eggs and larvae being incubated in water from the North Sea. All other batches of eggs and larvae were incubated on Bornholm. Incubation temperatures on Bornholm were 6 to $10^{\circ} \mathrm{C}$, in Helsinger 9 to $11^{\circ} \mathrm{C}$. Live embryos and larvae were screened for the presence of parasites at a magnification of 25 to 50 times. For transmission electron microscopy (TEM) larvae in Helsingør were fixed for 2 to 3 h in $2.5 \%$ cold glutaraldehyde buffered with cacodylate to about $\mathrm{pH} 7.4$ and subsequently stained with saturated uranyl acetate in $70 \%$ ethanol for $30 \mathrm{~min}$, dehydrated in ethanol and propylene oxide and embedded in epon. Sections were then stained with lead citrate.

\section{RESULTS}

The endoparasite was always located in the yolk sac, both in the egg stage and in young larvae. In most cases, only 1 parasite was observed, but a few larvae had up to 3 parasites (Fig. 1A). Under light microscopy the parasite typically appeared as a spherical body 

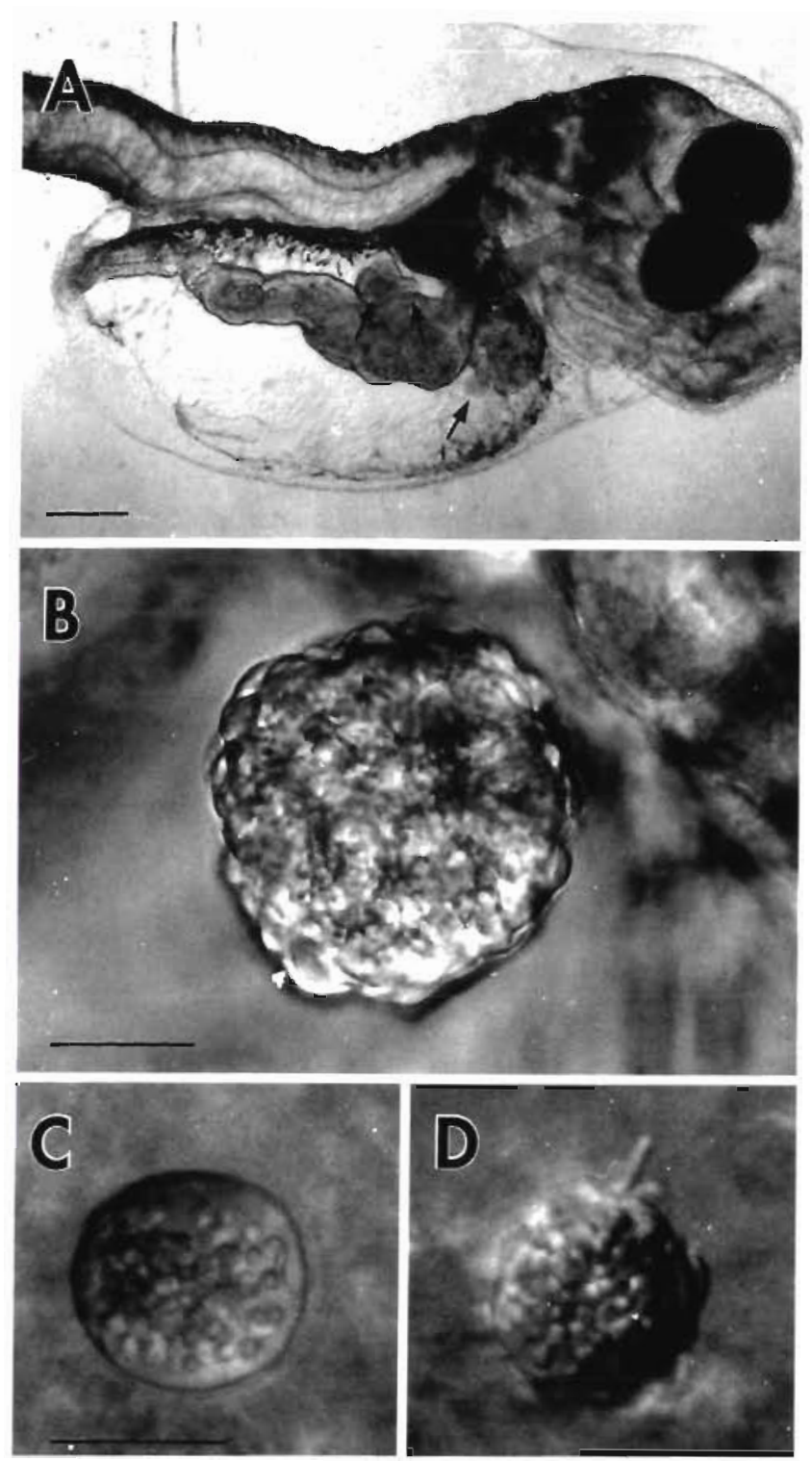

Fig. 1. Micrographs (interference contrast) of parasites in cod Gadus morhua larvae. (A) Yolk-sac containing 3 endoparasites (arrows). Scale bar $=200 \mu \mathrm{m}$. (B) High magnification of the parasite ventral to the alimentary tract in (A). Scale bar $=$ $25 \mu \mathrm{m}$. (C \& D) Smaller parasite (same specimen) from another cod larva photographed in situ (to same scale) within a few minutes. Note pseudopodia in (D). Scale bar $=20 \mu \mathrm{m}$

(Fig. 1B to D) floating in the otherwise transparent yolk, but the form could be more oblong, and moving pseudopodia-like extensions were observed (Fig. 1D). At higher magnifications, multiple bulges were visible over the entire surface (Fig. 1B). The parasite varied in size, with diameters ranging from 25 to $70 \mu \mathrm{m}$. Under TEM, 2 stages of the parasite were identified. One stage (Fig, 2A) was a sphere with an intact surface, packed densely with small mitochondria and granular endoplasmatic reticulum (Fig. 2B), and containing 2 types of vacuoles, one of which was very electron dense. We were unable to identify the nucleus, so the presence of more than one nucleus is highly improbable. The other stage is illustrated by the more ventral of the parasites in the larva in Fig. 1 A. It was characterized by numerous nuclei with peripherally condensed chromatin (Fig. 2C), few mitochondria with tubular cristae (Fig. 3C), and the surface exhibited invaginations beneath the external membrane. These invaginations separated adjoining nuclei, each of which was surrounded by many concentric layers of granular endoplasmatic reticulum (Fig. 2D), a few mitochondria and very small amounts of cytoplasm. The nuclei were predominantly located in the periphery, but plasma membranes were also observed around centrally positioned nuclei. Vacuoles containing an amorphous substance were evident throughout the organism. No flagellae or chloroplasts were observed. The membrane surrounding the multinucleated stage had an extension which was continuous with a layer of connective tissue on the serosal side of the larval gut (Fig. 3A, B).

The prevalence of the endoparasite in each batch of eggs or larvae is given in Table 1. For larvae, the prevalence is shown at the time of observation closest to the time of hatching, because the frequency of infested larvae, as judged from observations at 25 to $50 \times$ magnification, could drop to zero well before the end of the yolk-sac stage. The prevalence ranged between 0 and $30 \%$.

\section{DISCUSSION}

The endoparasite is a protist (tubular mitochondrial cristae) and the nuclei have conspicuous amounts of condensed chromatin in interphase, a feature typical of dinokaryons. Among the endoparasitic dinoflagellates, members of the order Syndinida parasitize metazoan body cavities, and the only other known example of yolk-sac infestations in marine fish larvae was caused by a member of that order (Cachon \& Cachon 1987). The chromosomes in the Syndinida differ from those of most other dinoflagellates as they are associated with basic proteins and never exhibit an arched fibrillar structure (Cachon \& Cachon 1987). During their trophic phase these parasites multiply their nuclei and form plasmodia, which give rise to new plasmodia; this is followed by cytoplasmic divisions until the formation of sporocysts, which liberate biflagellated dinospores (Cachon \& Cachon 1987). The trophont, which is the stage described in the present paper, loses its dinoflagellate morphology - sulcus, girdle and flagellae - in addition to some cytological and biochemical characteristics of dinoflagellates, and osmotrophy, a rare form of nutrition, is the rule (Cachon \& Cachon 1987). We 


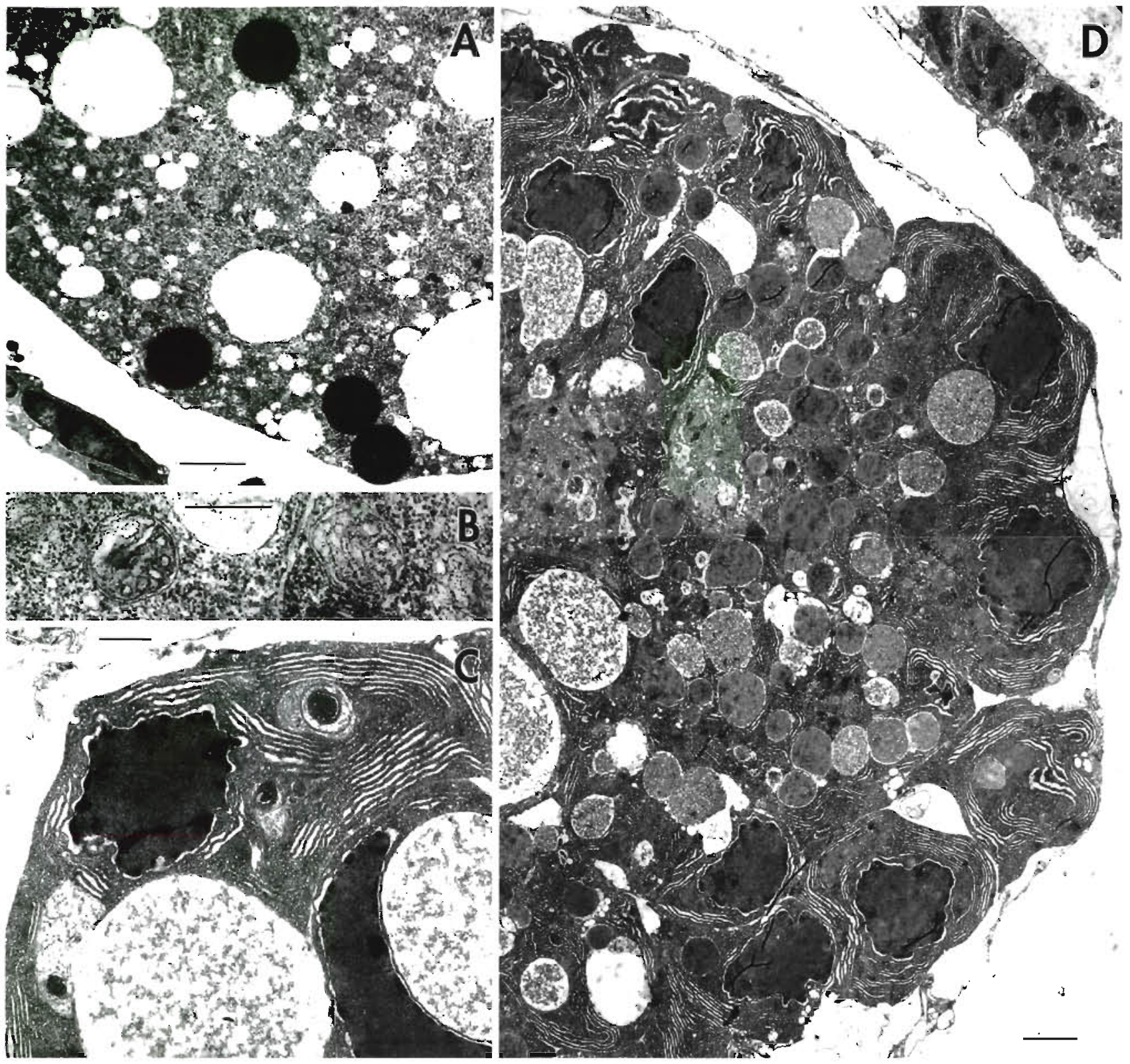

Fig. 2. TEM of 2 stages of the parasite in situ in cod Gadus morhua. (A) The apparently mononucleated stage close to fish tissue (bottom, left). Scale bar $=2 \mu \mathrm{m}$. (B) Two mitochondria with tubular cristae. Same specimen as in (A). Scale bar $=0.5 \mu \mathrm{m}$. (C) and (D) are from the specimen in Fig. 1B. (C) Multinucleated stage showing 2 nuclei with condensed chromatin surrounded by granular endoplasmatic reticulum. Large vacuoles contain an amorphous substance. Scale bar $=1 \mu \mathrm{m}$. (D) Multinucleated stage surrounded by a thin membrane originating from the fish. Note invaginations between peripherally located cells, and numerous vacuoles and few nuclei located centrally. Fish tissue in seen at the upper right. Scale bar $=2 \mu \mathrm{m}$

interpret its appearance under TEM as that of a young, mononucleate endoparasite which develops into a plasmodium which starts to break up into numerous mononucleated organisms. The external membrane of the multinucleated stage is formed by the host (Cachon \& Cachon 1987). As is the rule for endoparasitic dinoflagellates, the route of infestation is unknown in the present case. Hollande \& Cachon (1952) identified the zoospores of their parasite, Ichthyodinium chabelardi, but even when the yolk was inoculated, sardine eggs were not infested. A.t present, we cannot assess whether the parasite entered our cod embryos via the Baltic seawater or via the cod gametes.

The life cycles of Ichthyodinium chabelardi and of the parasite described here show some similarities. Initially, both parasites infest fish eggs in low numbers ( 1 to 3 per egg); they then seem to shift from a small, mononucleated stage to a large plasmodial form which 

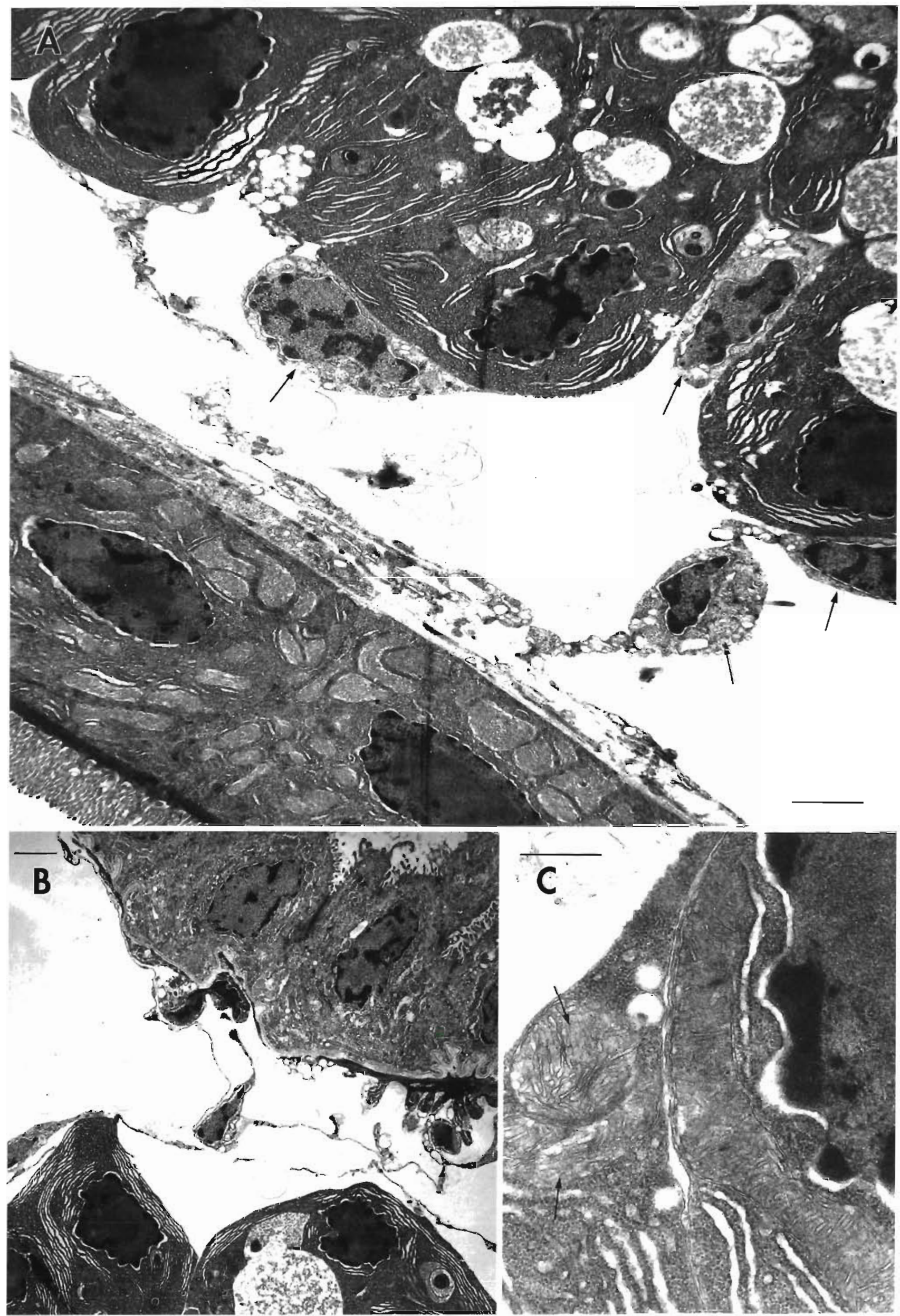
Table 1 Gadus morhua larvae and eggs: prevalence of infestation with endoparasites. Dates of fertilization and hatching are shown. For larvae, the day of examination is in days after hatching, for eggs in days after fertilization. Batch 8 (eggs) continues as Batch 6 (larvae). Batches 3 and 4 represent 1 group of embryos reared at 2 different locations (see text)

\begin{tabular}{|cccccc|}
\hline Batch no. & $\begin{array}{c}\text { Date } \\
\text { fertilized }\end{array}$ & $\begin{array}{c}\text { Date } \\
\text { hatched }\end{array}$ & $\begin{array}{c}\text { Day of } \\
\text { examination }\end{array}$ & $\begin{array}{c}\text { No. } \\
\text { sampled }\end{array}$ & $\begin{array}{c}\text { Prevalence } \\
(\%)\end{array}$ \\
\hline Larvae & & & & & \\
1 & 2 May & 18 May & 2 & 107 & 2 \\
2 & 26 May & 9 Jun & 1 & 20 & 25 \\
3 & 15 Jun & 29 Jun & 0 & 33 & 9 \\
4 & 15 Jun & 26 Jun & 4 & 20 & 30 \\
5 & 18 Jun & 29 Jun & 0 & 20 & 25 \\
6 & 10 Jul & 20 Jul & 2 & 20 & 15 \\
7 & 24 Jul & 5 Aug & 0 & 20 & 25 \\
Eggs & & & & & \\
8 & 10 Jul & & 4 & 37 & 13 \\
9 & 16 Jul & & 1 & 25 & 0 \\
\hline
\end{tabular}

yolk sac of infested larval sardines became opalescent and filled with parasites, which finally burst the yolk sac. The yolk sac of infested larval cod was transparent, and only a few multinucleated parasites were present. Whereas the infestation was lethal in case of sardines (Hollande \& Cachon 1952), we do not as yet know the implications for the health of larval cod. However, if the daughter cells of the multinucleated form of the endoparasite at some later stage seek to penetrate the larval tissues, the consequences may be severe for cod larvae, especially considering the high prevalences found in the present study. buds off its nuclei, surrounded by part of the cytoplasm. However, there seem to be 2 major differences between the sardine and cod endoparasites. Whilst the present parasite had numerous vacuoles dispersed throughout the cytoplasm, Ichthyodinium chabelardi contained a very large central vacuole, which in the mononucleated stages - the young trophonts as well as the cells derived from the plasmodium - occupied the central part of the cells, displacing the cytoplasm to the periphery (Hollande \& Cachon 1952). In contrast, the cells apparently ready to dissociate from the large trophont in larval cod contained very few and small vacuoles, and predominantly consisted of organelles necessary for protein synthesis. Another difference between the endoparasites of larval sardines and cod seems to be the aggressiveness of the infestation. The

Responsible Subject Editor: W. Körting, Hannover, Germany
Acknowledgements. The Ministry of Fisheries, Denmark, is acknowledged for financial and practical support.

\section{LITERATURE CITED}

Cachon, J., Cachon, M. (1987). Parasitic dinoflagellates. In: Taylor, F. J. R. (ed.) The biology of dinoflagellates. Bot. Monogr. 21: 571-610

Hollande, A., Cachon, J. (1952). Un parasite des oeufs de sardine: l'Ichthyodinium chabelardi, nov. gen., nov. sp. C. r. Acad. Sci, Paris (Sér. D) 235: 976-977

Hollande, A., Cachon, J (1953). Morphologie et évolution d'un péridinien parasite des oeufs de sardine (Ichthyodinium chabelardi). Station d'Aquiculture et de Pêche de Castiglione (Alger) 4:7-17

Rosenthal, H. (1967). Parasites in larvae of the herring (Clupea harengus L.) fed with wild plankton. Mar. Biol. 1: $10-15$

Manuscript first received: December 8,1992 Revised version accepted: February 23, 1993

Fig. 3. TEM of multinucleated stages of the endoparasite in Gadus morhua. (A) Parasite located dorsal to the alimentary tract shown in Fig. 1A. Note that membrane surrounding the parasite is continuous with the serosal side of the larval intestine (lower left). Arrows indicate fish cells in the membrane. Scale bar $=2 \mu \mathrm{m}$. (B) Same specimen as in Fig. 1B, showing host-parasite relationship. Fish 'stomach' is seen at the upper right. Scale bar $=2 \mu \mathrm{m}$. (C) Details of 2 cells. In the right cell, a large mitochondrion and part of the nucleus are seen. Part of 2 mitochondria (arrows) with tubular cristae are seen in the left cell, in addition to granular endoplasmatic reticulum. Scale bar $=0.5 \mu \mathrm{m}$ 